\title{
A földrajzi személyi hungarikum feldolgozásának problematikája
}

\author{
Ungváry Rudolf \\ Országos Széchényi Könyvtár; PIM Digitális Bölcsészeti Központ \\ ungvaryr@gmail.com
}

\section{Bevezető}

A magyar vagy magyar vonatkozású szerzőknek, csakúgy, mint külföldi társaiknak, van két alapvető földrajzi meghatározottsága: a születési és a halálozási helyük. Ezeknek azért van jelentőségük, mert arról tájékoztatnak, hogy honnan származik a szerző, illetve arról, hogy hol halt meg. A magyar és magyar vonatkozású szerzők esetében tárgyalt földrajzi nevek mind magyar vonatkozásúak, ezért hungarikumnak tekinthetőek. Így bevezethetjük a földrajzi személyi hungarikum fogalmát. Ennek minősül minden olyan földrajzi hely, amely magyar vonatkozású személyek születési és halálozási helye, külföldi állomáshelye, hungarikum kiadási helye.

\section{A feldolgozás nehézségei}

A PIM Digitális Bölcsészeti Központban jelenleg az adatbázisban szereplő személyek helyadatainak a névtéri ${ }^{1}$ feldolgozása folyik. Ennek lényeges része, hogy a forrásokban szereplő szerzők születési és halálozási helyneveit azonosítani kell:

- meg kell állapítani, hogy a forrásban szereplő földrajzi név a valóságban milyen formában létezik, és

- milyen magasabb igazgatási egységhez tartozik, végül pedig

- be kell hasonlítani a jelenleg épülő névtérbe, ill. annak földrajzinév-terébe, meg kell állapítani, hogy van-e megfelelője, ha van, akkor az milyen hivatalos alakban szerepel, ha pedig nincs, akkor föl kell venni ${ }^{2}$

A könyvtárak egységesített besorolási adataiban szereplő helynevek mind ellenőrzött, megbízható névalakok, ezért feldolgozásuk - elsősorban informatikai eszközökkel - jól támogatható. A PIM adatbázisában szereplő források túlnyomó része ezzel szemben hagyaték, kis része pedig nyomtatott könyv. A bennük szereplő földrajzi nevek az eddigi tapasztalatok alapján megbízhatatlanok.

A helynevek egy részének ma van hivatalos, államilag nyilvántartott nevük. ${ }^{3} \mathrm{~A}$ történelmi Magyarországnak (beleértve Horvátországot is) volt hivatalos helységnévtára. ${ }^{4}$ A feldolgozandó születési és halálozási nevek jelentős többsége település (pl. Csíkménaság, London [Finnország], Pozsony).

1 A földrajzi nevek és névterek irodalmát illetően lásd Ungváry [11], [12] és [13].

2 A jelenleg operatívan fejleszthető földrajzi névteret [8] a Relex [9] kezeli. Az eredményt majd egyeztetve véglegesíteni kell a Nemzeti Névtér béta változatának [7] végleges, „élesben” is használható állományával. Az utóbbinak ugyanis nincs még szerkesztősége, és maga a szerkesztőségi rendszer sincs még véglegesen befejezve http://abcd.hu/2019/05/13/nemzeti-nevter-beta/.

3 A szakirodalomból itt csak Fábián Pál és Földi Ervin [3], továbbá Győry Erzsébet [4] munkájára utalok.

4 Ennek a térképészeti gyakorlathoz hasonlóan a legutolsó érvényes kiadását vettem figyelembe [5]. 
A másik része településrész (külterületi lakott hely, mint pl. Ajtós, Csórompuszta, Kisújszálási csorba). Ezek központi, állami, hivatalos névadása jelenleg sem teljes, ezeket a földrajzi neveket többnyire csak a helyi igazgatás hatáskörében tartják nyilván. ${ }^{5}$

A helynevek másik nagy csoportját a névváltozatok (szinonimák) alkotják: a ma is általánosan használt szinonimák (pl. Peleske (=Pölöske)), a helytélő̋ és tájnevek, amelyeket csak a szóban forgó településen és környékén használnak (pl. Hosszúhavas (=Rakottyástelep [Csík vármegye]), Mándibokor (=Mandabokor [Nyíregyházi határ])), idegen nyelvú névváltozatok (pl. Găiceana (=Gajcsána [Moldva])), végül pedig a korábbi (pl. Eszék (=Osijek)) és a történelmi nevek (pl. Boroszló (=Wrocław), Nyulak-szigete (=Margit-sziget)).

Aminek nincs hivatalos neve, az a magyar térképészeti gyakorlatnak megfelelően szerepel a földrajzi névtérben. Számos történelmi név esetében a magyar történelemtudomány és régészet gyakorlatának megfelelő forma a mérvadó.

Nagyon sok külföldi földrajzi név is szerepel az állományban. Jelentős részük nem hivatalos, hanem elavult vagy hibás névalak, vagy csak a településen vagy annak környékén használt, ún. helytélő név. A kisnyomtatvány-forrásokban (pl. gyászjelentések), iskolai értesítőkben, katonai veszteség- és hadifogolyjegyzékekben rendkívül gyakoriak a helytélő nevek és az akár az érthetetlenségig eltorzult elírások. A keleti és a balkáni fronthoz kapcsolódó nevek esetében, hivatalos katonai topográfiai térképek hiányában különösen nehezen rekonstruálható, hogy a megadott helynév milyen mai, hivatalosnak számító névnek felel meg.

Mindezek miatt nem lehet a forrásokban rendelkezésre álló névállományt egészében intellektuális előfeldolgozás nélkül, automatikusan összehozni sem a meglévő hivatalos földrajzinév-állományokkal (pl. a KSH vagy a FÖMI állományaival), sem nemzetközi rendszerek (pl. a Geonames vagy a Wikipédia) neveivel, de magával a Relex [9] által kezelt állománnyal [8] sem. ${ }^{7}$ Lényegében minden egyes nevet ellenőrizni kell, amely nem felel meg maradéktalanul a Relex földrajzi névterében szereplővel. De még azokat is ellenőrizni kell, amelyek első lépésre névalak dolgában teljesen azonosak a földrajzi névtér valamelyik névalakjával, mivel a homonim nevek következtében egy Alexandriából, Alexandrovóból, Almásból vagy egy Annamajorból akár több tucat is létezhet.

5 A normatív (hivatalosnak tekinthető) külterületi településrészeket a történelmi Magyarország vonatkozásában a teljesség igényétől meglehetősen távoláló, 1913-as helységnévtár [5] tartalmazza. A mai magyarországi külterületeket pedig a Földi Ervin által szerkesztett 1971-1982es földrajzinév-tár [1].

6 A helytélő név a tájnévtől (Rábatöttös helyett Rábatöttős) abban különbözik, hogy nem nyelvjárásitájnyelvi név (Mezőkeresztes helyett Borsodkeresztes). A két típus többnyire nem választható szét, a helytélő nevek többsége tájnévnek is tekinthető. A kifejezést a KSZ/5 vezette be [8].

7 A földrajzi névtér Relex által kezelt változata maradéktalanul tartalmazza a KSH és a FÖMI névállományát. Ezekben szinonim nevek nincsenek. A kitüntetett névalak (deszkriptor) mindig az utóbbiakban nyilvántartott név. A FÖMI állománya, a „Magyarország Földrajzinév-tára” csak belső használatban tekinthető meg (http://www.ftf.bfkh.gov.hu/portal/index.php/termekeink/ magyarorszag-foeldrajzinev-tara) [15] 
A forrásokban rögzített születési és halálozási helyek feldolgozásának eredményei

A feldolgozandó nevek mennyiségéről az 1. táblázat ad felvilágosítást.

\begin{tabular}{|l|r|}
\hline település és egyéb nem közterület & $26728 \mathrm{db}$ \\
\hline budapesti közterület & $1620 \mathrm{db}$ \\
\hline összesen & $28348 \mathrm{db}$ \\
\hline
\end{tabular}

1. táblázat. A feldolgozandó nevek

A feldolgozáshoz betöltöttük a PIM teljes névállományát és behasonlítottuk (összevetettük) a Relex által kezelt földrajzi névtér neveivel. Voltak nevek, amelyek megfeleltek a névtérben szereplő neveknek, és voltak, amelyek nem. Az utóbbiakhoz vagy meg lehetett találni a megfelelő helyes névtéri nevet, vagy rá lehetett jönni a névtéren kívüli, hosszas, intellektuális kereséssel a megfelelő névre. Ennek során a földrajzi névtér 130000 névből (lexikai egységből) álló állománya kb. 1\%-kal bővült.

Mindez arra utal, hogy a magyar vonatkozású belföldi, történelmi magyarországi és ezen kívüli neveket tartalmazó jelenlegi földrajzi névtér magyar vonatkozásban már közel teljesnek tekinthető. A mostani feldolgozás során keletkezett településnevek kisvárosok (pl. Bellaire, Ohio állam egyik négyezer lakosú városkája), olykor városrészek (pl. Gersthof, Bécs egyik városrésze), vagy rendkívül kis falvak (pl. Boldirjevka a Don közelében) voltak.

Az állomány 33\%-ának feldolgozása után voltak

- a meglévő névalakok megegyezése következtében könnyen azonosítható nevek, a feldolgozott állomány 55\%-a;

- behasonlítandó (nem azonosított) nevek, amelyeket szellemi munkával azonosítani kellett, a feldolgozott nevek 45\%-a;

- ezen belül a sikeresen behasonlított (azonosított) nevek aránya (szellemi ráfordítással, egyeztetéssel és behasonlítással, más forrásokban való kutatással): 81\% (teljes feldolgozott állomány 36\%-a)

- a sikeresen azonosított nevek közül a szinonimák, a helytélők, az elavultak és a hibás nevek aránya, amelyekhez meg lehetett találni a megfelelő hivatalos, ill. a térképészeti gyakorlatban használt vagy a névtérben meglévő, vagy pedig a névtérben addig nem szerepelő nevet: 57\% (a teljes behasonlítandó állomány 46\%-a)

- a sikeresen azonosított nevek közül azok, amelyeket közvetlenül meg lehetett feleltetni a névtérben szereplő vagy addig még ott nem szereplő, megfelelő, hivatalos, ill. a térképészeti gyakorlatban használt nevekkel: 43\% (a teljes behasonlítandó állomány 35\%-a)

- ezen belül a végképp azonosítatlannak bizonyult nevek aránya: 19\% (a teljes feldolgozott állomány 9\%-a)

Figyelemre méltó tehát, hogy a forrásokban szereplő nevek közel fele nem olyan volt, hogy a névalakjukból egyértelműen kiderült volna, hogy pontosan hol található a születési vagy halálozási hely. Ezek egy részénél ránézésre csak sejthető volt vagy az ország vagy a nyelvterület, ahol fekszenek. 
A feldolgozási jellemzőket a 2. alábbi táblázat foglalja össze:

\begin{tabular}{|c|c|c|c|}
\hline & $\begin{array}{l}\text { teljes állomá- } \\
\text { nyon belül }\end{array}$ & $\begin{array}{l}\text { behasonlí- } \\
\text { tandó neve- } \\
\text { ken belül }\end{array}$ & $\begin{array}{l}\text { sikeresen } \\
\text { azonosította- } \\
\text { kon belül }\end{array}$ \\
\hline megegyező nevek & $55 \%$ & & \\
\hline \multirow[t]{2}{*}{ behasonlítandó nevek } & $45 \%$ & & \\
\hline & $100 \%$ & & \\
\hline \multirow{3}{*}{$\begin{array}{l}\text { végképp azonosítatlan név } \\
\text { sikeresen azonosított (azonosított) } \\
\text { név }\end{array}$} & $9 \%$ & $19 \%$ & \\
\hline & $36 \%$ & $81 \%$ & \\
\hline & $(45 \%)$ & $100 \%$ & \\
\hline $\begin{array}{l}\text { sikeresen azonosított név azonos a } \\
\text { hivatalos, ill. térképészeti gyakorlat } \\
\text { nevével (deszkriptor, kitüntetett név) }\end{array}$ & $15 \%$ & $35 \%$ & $43 \%$ \\
\hline $\begin{array}{l}\text { sikeresen azonosított név azonos } \\
\text { valamelyik névváltozattal (nem } \\
\text { deszkriptor) }\end{array}$ & $20 \%$ & $46 \%$ & $57 \%$ \\
\hline & (35\%) & & $100 \%$ \\
\hline
\end{tabular}

2. táblázat. Feldolgozási jellemzők

A hibák egy része egy vagy több karakter elírásából adódott. Ezek egy részénél csak asszociációk, hasonlóságok révén lehetett rátalálni a valószínúsíthetően helyes névalakra. Például:
Alabor völgy
Talabor-völgy

Más esetekben a vonatkozó személlyel kapcsolatos lehetséges adatbázisokban kellett keresni. Például

Alsómartic

Alsónastic (1899 után Alsóneszte).

Palló János (1882-) tábornok hibás születési helyét a Hadtörténeti Intézet és Múzeum egyik eldugott adattárában lehetett azonosítani a születési hely helyes nevével, amelyet az életrajzában adtak meg.

Apolda

Apold

Mivel Krausz András Kis- és Nagy-Küküllő vármegyékben volt lelkész, átnézve a két vármegye összes települését, a megtalált Apold lehetett a legvalószínúbb helyes név. 
Balazkoje

Braile Mocrin mocsarak
Hrîstoforivka

Szúnyoghy Szúnyog Péter itt eshetett el 1941 augusztusában. A Hadtörténelmi Levéltárban talált adatok szerint a magyar csapatok akkor DélUkrajnában állomásoztak.

Egyedülaz „Ukrainiendeutsche” honlapjain böngészve volt felfedezhető, hogy ez egy 1842-ben alapított német falu (Neu-Danzig) Dél-Ukrajnában, amelynek egyik neve a 19. század végétől Hrîstoforivka, és egy helyt élő neve Balackoje, amelyet a korabeli magyar hadvezetés használt hallomásból és pontatlanul.

Mačini mocsarak

Az előtagról fel kellett tételezni, hogy az Braila kikötőváros a Duna-delta közelében, mert ezen a területen vannak a mocsarak. A „Braila” és a „Brăila” és a "mocsár” keresőszavakkal előkerült egy forrás (Magyar Botanikai Lapok) és benne a szövegrész: „Macintól Isaccea-ig a Duna dobrogeai oldala elmocsarasodik”. A Braila közelében fekvő Macsin szócikkben szerepel a „Brațul Măcin” („Macsniholtág”). Feltehetően ennek mocsaras környékéről van szó.

A nehézségek más részét az eldugott, félreeső helyeken fekvő, vagy nagyon távoli települések nevei okozták. Például:

Agoncy

Akhalciay
Ambohitralanana

Benyovszky Móric halálának helye, Agoncy tengerparti település Madagaszkár északi részén, Sava tartomány Antalaha kerületében; Benyovszky Móric angol nyelvű Wikipédia-szócikkében szerepelt a mai, földrajzilag azonosítható név.

Tiroyan P. Jákob (1863-) apostoli vagy keleti örmény katolikus pap születési helye, feltehetően Örményország vagy Törökország vagy Bulgária egyik aprófalva, amely egyetlen weben elérhető térképen sem szerepel ezen a néven, és az is lehet, hogy névelírás. Hosszas kutatás után is kinyomozhatatlan maradt.

A hibás adatok száma viszonylag magas, és viszonylag nagy a megállapíthatatlan nevek aránya is. Algoritmikus módszerek csak kis hatásfokkal alkalmazhatók, mivel csak ritka esetekben van csupán egy-két karakterben eltérő névalak, de még a valamennyire hasonló név sem gyakori a hibás nevek esetében. Ebből következően a földrajzi személyi hungarika feltérképezése meglehetősen hosszú időt és nagy behasonlítási-keresési ráfordítást igényel. 
Az azonosításhoz azonban nem elég, hogy azonosítani kellett a pontos, hivatalos vagy a magyar térképészeti gyakorlatban elfogadott helynevet, mert a puszta név alapján nem lehet egyértelműen megállapítani, hogy hol fekszik. Legfeljebb úgy, hogy a kézikönyvekben vagy az interneten utána nézünk, de ez többnyire nem vezet könnyű eredményre, mert a nevek jelentős része homonim. Azaz ugyanaz a névalak sok különböző települést jelöl.

Például a London helynevet szerte a világon 17 település viseli, csak az Egyesült Államokban 10 település. Antalmajorból Magyarországon több mint egy tucat található, és ezek bármelyike lehet születési vagy halálozási hely a forrásokban.

A nevekhez meg kellett állapítani azt az igazgatási egységet is, ahová tartozik, és ha ez nem szerepelt még a névtérben, akkor azt is újként föl kellett venni. Ha pedig nem szerepelt még a névtérben, hogy az adott igazgatási egység milyen átfogóbb igazgatási egységhez tartozik, akkor az egész láncolatot föl kellett venni újként.

Egy 19. századi németséggel írt Lemberg környéki település nevének azonosítása a mai, hivatalos nevével a következő, egymás után feltárt láncolaton keresztül vezetett eredményre: Blatocerkiew, onnan Belaja Zerkow, onnan Bjelaja Cerkovi, végül Bila Cerkva. Atelepülés azóta többszöris államot, nyelvet és írásrendszert cserélt, egyes névváltozatok el is tűntek, ki is vesztek a köztudatból. Az ilyen jellegű munka időigényes kereséssel jár.

\section{A földrajzi személyi hungarikum területi szórása}

A személyek gyakran nem a mindenkori Magyarországon, nem is magyar nyelvterületen születtek vagy haltak meg, és sok esetben soha nem is éltek a mindenkori Magyarországon. Ez arról tanúskodik, hogy milyen a magyar kultúra területi integrációs képessége. Hogy honnan, mely országokból, régiókból történt meg a tudáshordozók beáramlása és megsemmisülése. Más szóval mennyire ágyazódott be Magyarország személyileg a világ - és legfőképpen Európa és vele együtt az euroatlanti kultúra - vérkeringésébe?

Hipotézisként megkockáztatom, hogy más nemzeti kultúrákhoz képest a magyar kultúra esetében valószínűleg nagyobb a külföldi releváns születési helyek aránya. Ezt más államok adatbázisaival való összehasonlító vizsgálatokkal lehetne tisztázni.

A halálozási helyek külföldi szórása a beáramlással és befogadással ellentétesen, áttételesen a magyarországi magyar kultúra veszteségeiről ad területi képet. Az utóbbiak száma ugyancsak rendkívül magas. Feltűnően sok a nyugat-európai, az amerikai egyesült államokbeli és a dél-amerikai. Mindez szorosan összefügg a különböző időkben (1849, 1919, 1938-39, 1945 és 1956 utáni) lezajlott kivándorlási, menekülési hullámokkal. Ugyanakkor szinte nincs olyan kontinense, országa/gyarmata a világnak, amelyhez ne kapcsolódna magyar vagy magyar vonatkozású szerző halálozási helye. A másik átlagon felüli sűrűsödési hely a keleti hadszíntér, Oroszország és a Szovjetunió, beleértve a középázsiai és távoli-keleti területeket is. Ez utóbbi dolgában bizonyára a német nyelvterületen is hasonló a helyzet. Nemzetközi összehasonlításhoz pontos adatok egyelöre nem állnak rendelkezésre. 


\section{Hasonló munkák}

Király Péter és Kiséry András jelenleg Demeter Tibor részben kéziratos írói bibliográfiája [2] alapján dolgozza fel azoknak a nyomdáknak a földrajzi helyeit, amelyekben magyar könyveket nyomtattak a világon. A munkáról a Facebook közösségi hálózaton számolt be Király Péter [6].

Ebben a munkában kb.400településtjelölő, 2500 körülinévalakot(névváltozatot)emeltek ki, ezek mindegyike nyomdahely, következésképp város, amelyekről sok dokumentáció és interneten letölthető forrás áll rendelkezésre. Ebből adódóan azonosításuk egyszerűbb, mint egy XIX. századi németséggel írt pusztanévé Lemberg környékén. A nehézség itt elsősorban a kisebb-nagyobb elírásokból adódott, és a hivatalos névalakok megkeresése igényelt több munkát. Sok mindent meg lehetett oldani számítástechnikai eszközökkel (pl. a Geonames nevű földrajzinév-adatbázis kereső alkalmazásprogramozási felületével), többek között a fontossági előfordulási statisztikák, hasonlósági keresések lefuttatása, közeli írásképek esetében. Legfeljebb az egykori szovjet városok cirill és transzliterált neveivel akadtak gondok.

Munkájuk konklúziójaként - a kiadási-nyomtatási évek alapján - kronológiai rétegződést is megvalósítottak, azaz idóbeli bontásban, kattintások sorozatával interaktív térképek jeleníthetők meg.

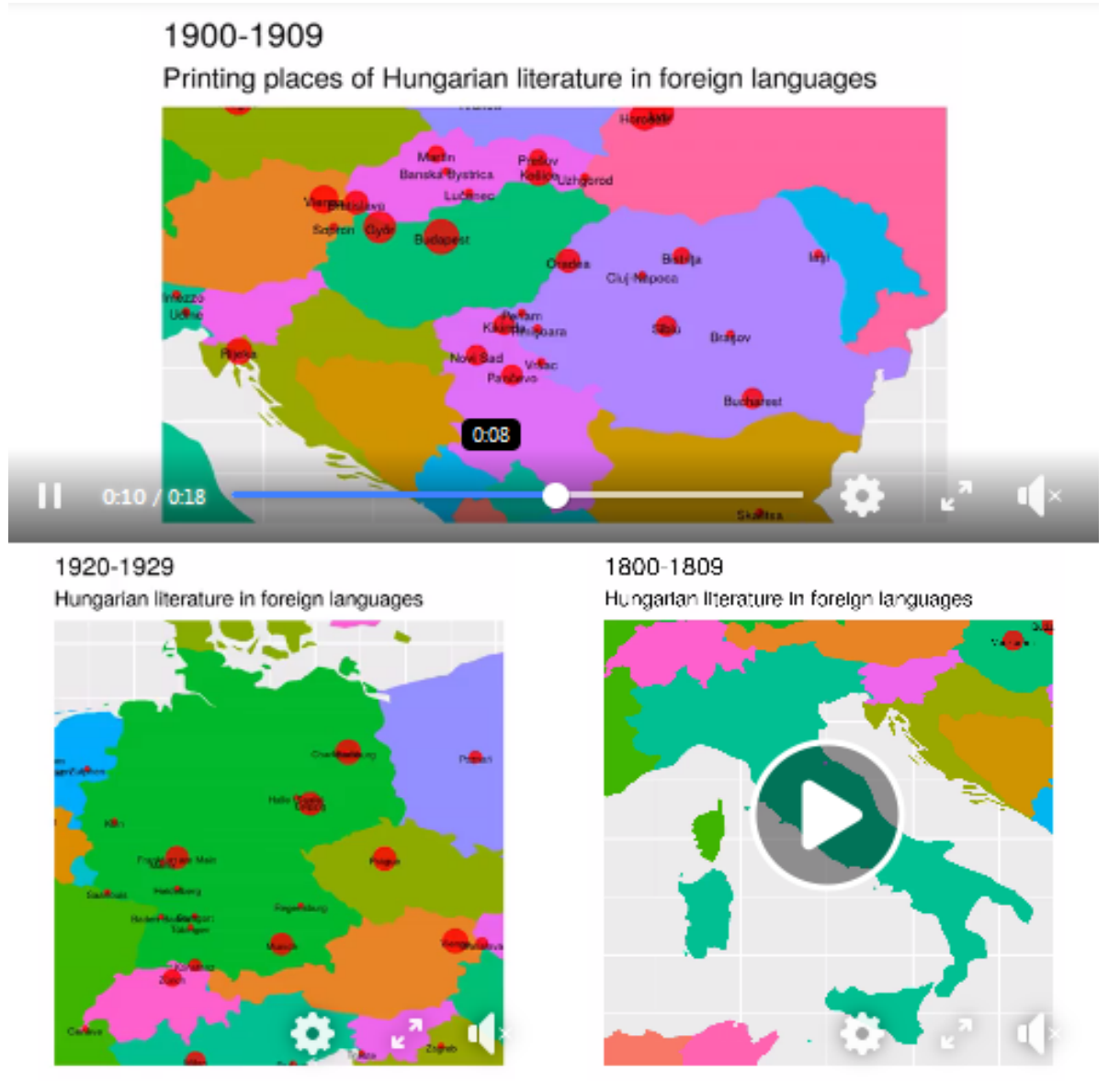

1. ábra. Részletek a magyar könyveket nyomó nyomdák interaktív térképéből 
Nagyjából ezzel egy időben Szakadát István a Nemzeti Névtér béta változatának személynévterében szereplő emberek születési helyeinek térképét mutatta be a közösségi hálózaton Horvátország nélkül a történelmi Magyarország területén [10] https://www.facebook.com/ photo?fbid=10158153057952981\&set=a.10150592363867981 .

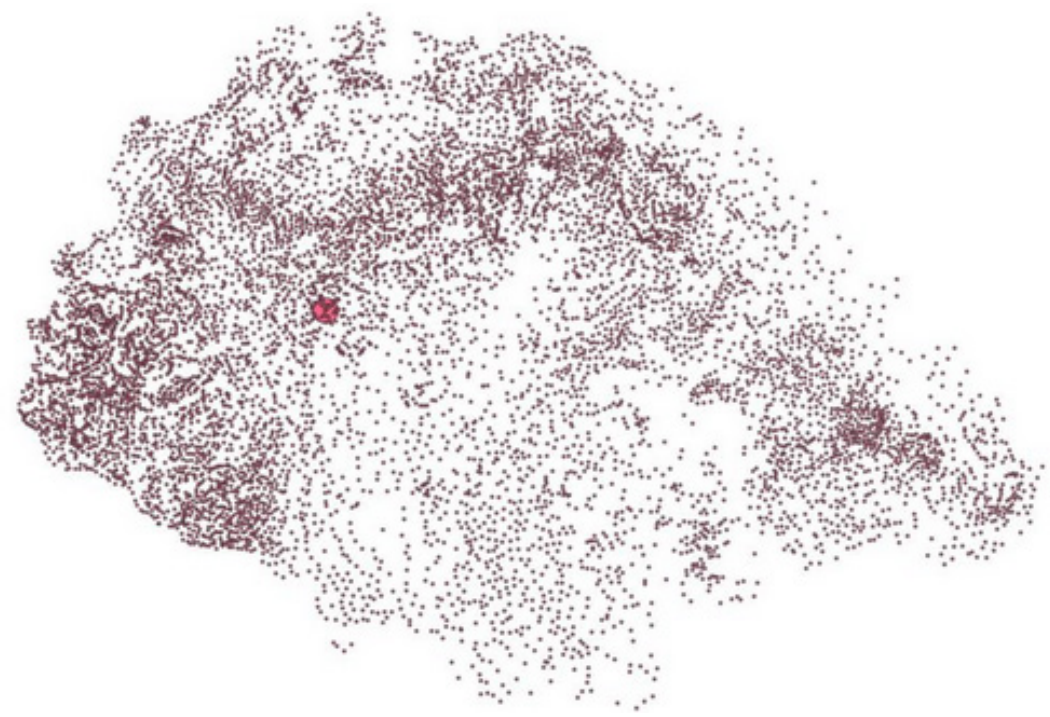

2. ábra. A Nemzeti Névtérben szereplő, és a történelmi Magyarországon született személyek születési helyei.

A pontok nagysága jelzi, hogy az adott településen hány névtérben szereplő ember született. Ezt még kontrasztosabban jeleníti meg a következő térkép:

https://www.facebook.com/photo.

php?fbid=10158153125377981\&set=p.10158153125377981\&type=3 [14]

Az ország kelet-alföldi, például nyírségi része feltűnően szegényes nevekben. Az is felismerhető, milyen mértékben növekszik a születési helyek sűrüsége nyugat és a Felvidék felé.

\section{Összegzés, kitekintés}

Mind a PIM-ben zajló, itt ismertetett munka, mind Király és Kiséry, mind pedig Szakadát kutatásai lehetőséget adnak arra, hogy az általuk alkalmazott informatikai eszközök segítségével számszerú eredmények szülessenek a kulturális folyamatok történelmi hátteréről, többek között az integrálóképesség és a veszteségek területi eloszlásáról. Az interaktív megjelenítés egyben a közérdeklődést is jobban kielégíti.

Hasonlóképpen feldolgozhatók és elemezhetők a szomszéd államok, de nem utolsó sorban Németország, Lengyelország és Oroszország nemzeti könyvtári adatbázisaiban az egységesített besorolási személynevek születési és halálozási helyei és évei. 


\section{Bibliográfia}

[1] Magyarország földrajzinév-tára I. Fontosabb domborzati, táj- és víznevek. szerk.: Földi Ervin. Budapest, Mezőgazdasági és Élelmezésügyi Minisztérium Országos Földügyi és Térképészeti Hivatal, 1971.

Magyarország földrajzinév-tára I. Fontosabb domborzati, táj- és víznevek. szerk.: Földi Ervin. 2. kiadás. Budapest, Kartográfiai Vállalat, 1982.

Magyarország földrajzinév-tára II. [Baranya megye; Győr-Sopron megye; Somogy megye; Vas megye; Veszprém megye; Zala megye; Csongrád megye; Fejér megye; Komárom megye; Tolna megye; Bács-Kiskun megye; Békés megye; BorsodAbaúj-Zemplén megye; Heves megye; Pest megye; Budapest; Nógrád megye; Szolnok megye; Hajdú-Bihar megye; Szabolcs-Szatmár megye] szerk.: Földi Ervin. Budapest, Kartográfiai Vállalat, 1978-1981. [19 kötetben közreadva]

[2] Bibliographia Hungarica. Magyar szépirodalom idegen nyelven. 1-15. kötet. Gyūjt. és leírta Demeter Tibor. Budapest, M. Külügymin., 1957-1958.

[3] Fábián Pál, Földi Ervin, Hőnyi Ede: A földrajzi nevek helyesírása. Budapest, Akadémiai Kiadó, 1998.

[4] Győrffy Erzsébet: A hivatalos név terminus. In: Magyar Nyelvjárások. 50. (2012.) p. 27-35. http://mnytud.arts.klte.hu/mnyj/50/03gyorffy.pdf

[5] A magyar szent korona országainak helységnévtára : Orts-Lexicon der Länder der Ungarischen Krone. szerk. és kiad. a Magyar Királyi Központi Statisztikai Hivatal. Budapest, Magyar Királyi Központi Statisztikai Hivatal, 1913.

[6] [Király Péter: Európai magyar nyomdák]. Facebook. 2021.02.18. https://www.facebook.com/pkiraly/posts/10160071953561808

[7] Nemzeti Névtér béta változata. http://abcd.hu

[8] Földrajzi névtér. A Nemzeti Névtér béta változatának Relexszel kezelt operatív formája. Szerk. Ungváry Rudolf. [Budapest, Országos Széchényi Könyvtár]. 2018http://abcd.hu/foldrajzi-nevter/

[9] Relex (RElációk és LEXikai egységek) több felhasználós kliens-szerver alkalmazás névterek... osztott felhasználására egy és többnyelvű környezetben az interneten keresztül. Budapest: Országos Széchényi Könyvtár; MOKKA, 2012-. http://mokka.hu/relex/index.html

[10] [Szakadát István: a Nemzeti Névtér béta változatának személynévtere. Születési helyek]. Facebook. 2021.01.06.

https://www.facebook.com/ photo?fbid=10158153057952981\&set=a.10150592363867981

[11] Ungváry Rudolf: A földrajzi nevek és szerepük az információkeresésben. Nemzetközi fejlődés, problémák és tapasztalatok a Köztauruszban és Geotauruszban. In: Könyvtári figyelő. 54. (2008.) 3. sz. http://ki.oszk.hu/ kf/2010/10/a-foldrajzi-nevek-es-sz erepuk-az-informaciokeresesben/ https://epa.oszk.hu/00100/00143/00068/pdf/EPA00143_konyvtari_ figyelo_2008_3_395-428.pdf 
[12] Ungváry Rudolf, Pászti László: Földrajz nevek és szerepük az információkeresésben. Nemzetközi fejlődés, problémák és tapasztalatok a Köztauruszban és Geotauruszban. In: Könyvtári figyelő. 54. (2008.) 3. sz., p. 395428.

http://ki.oszk.hu/kf/2010/10/a-foldrajzi-nevek-es-szerepuk-azinformaciokeresesben/ https://epa.oszk.hu/00100/00143/00068/pdf/EPA00143_konyvtari_ figyelo_2008_3_395-428.pdf

[13] Ungváry Rudolf: Névterek és földrajzinév-tárak. Észrevételek a Magyarország Földrajzinév-tára jövőbeni továbbfejlesztéséról. In: Tudományos és Múszaki Tájékoztatás. 63. (2016.) 4. sz., p. 135-157. https://epa.oszk.hu/03000/03071/00095/pdf/EPA03071_tmt_2016_04_135157.pdf

[14] [Szakadát István: a Nemzeti Névtér béta változatának személynévtere. Születési helyek. Újabb térkép]. Facebook. 2021.01.06.

https://www.facebook.com/photo. php?fbid=10158153125377981\&set=p.10158153125377981\&type=3

[15] Lechner Tudásközpont. Magyarország Földrajzinév-tára. http://www.ftf.bfkh.gov.hu/portal/index.php/termekeink/magyarorszagfoeldrajzinev-tara 